\title{
Reinventing the Dutch tax-benefit system: exploring the frontier of the equity-efficiency trade-off
}

\author{
Ruud A. de Mooij
}

Published online: 13 September 2007

(C) Springer Science+Business Media, LLC 2007

\begin{abstract}
European governments aim to raise labour supply, cut unemployment and, at the same time, maintain social cohesion. Yet, economists have stressed the tradeoff between these objectives. This paper reviews the key policy insights from optimal tax theory to identify options for reform in the tax-benefit system that can potentially improve the equity-efficiency trade-off. Using a comprehensive applied general equilibrium model, we then explore whether reforms along these lines in the Dutch tax-benefit system raise employment without sacrificing equality. The analysis reveals that selective tax relief for elastic secondary earners and low-skilled workers have this potential. A flat income tax structure, possibly combined with a negative income tax, worsens the equity-efficiency trade-off.
\end{abstract}

Keywords Tax-benefit system · Labour supply · Unemployment · The Netherlands · Applied general equilibrium

JEL Classification D31 $\cdot$ D58 $\cdot$ H24 $\cdot$ J22 $\cdot$ J68

\section{Introduction}

As part of the Lisbon agenda to become the most competitive and dynamic economy in the world, increasing the employment rate is a top priority for European governments. The aim is especially to better integrate particular groups in the labour market, such as the low-skilled, women, elderly and social benefit recipients. To achieve this

\footnotetext{
R.A. de Mooij ( $\triangle)$

CPB Netherlands Bureau for Economic Policy Analysis, Den Haag, The Netherlands

e-mail: radm@cpb.nl

R.A. de Mooij

Tinbergen Institute and CESifo, Erasmus University Rotterdam, Rotterdam, The Netherlands
} 
goal, countries are now restructuring their welfare states. At the same time, however, European governments want to preserve social cohesion that is traditionally a major objective of the welfare states. The twin objectives ignore the fundamental trade-off between equity and efficiency, which is inherent in the design of taxbenefit systems. It raises the question whether reforms are feasible that improve the equity-efficiency possibility frontier. This paper analyses the opportunities for such reforms.

The paper starts by reviewing key insights from optimal tax theory to identifying the factors determining the equity-efficiency possibility frontier. We discuss important results from applied optimal tax analyses, which give guidance to potentially promising directions for reform. The optimal tax models, however, usually contain only one or two distortions, apply aggregate income distributions for the total population, and do not differentiate between agents. Moreover, most studies apply data for the United States, which has a more dispersed income distribution than is common in Europe and a smaller share of part-time work. This paper analyses reforms in the Dutch tax-benefit system by using an applied general equilibrium model for the Netherlands. The model is comprehensive in describing various distortions induced by redistributive taxation. In particular, it encompasses decisions at the intensive margin of labour supply of males and females, the participation decision of secondary earners in couples, and the job acceptance decision of the unemployed. The elasticities at various decision margins are calibrated on the basis of existing empirical evidence. For various household types and decision margins, population densities are calibrated on the basis of Dutch income distributions.

The model simulations yield a number of policy conclusions. Selective in-work tax credits for low labour incomes and secondary earners in couples have the potential to raise employment without sacrificing equality. These selective tax credits should be targeted at decision margins with the highest elasticities and with the highest population densities. If they shift the marginal tax burden unto more densely populated groups, e.g. just above the minimum wage in the Netherlands, they tend to reduce employment. Flat tax reforms aimed to reduce top marginal income tax rates turn out to worsen the equity-efficiency trade-off. The reason is that they shift the marginal tax burden towards more elastic secondary earners. Removing the poverty trap by switching from means-tested income transfers to a general basic income exacerbates the distortionary impact of the tax-benefit system by raising the marginal tax burden on the densely populated middle income groups.

The rest of this paper is organised as follows. Section 2 discusses the potential for efficiency-enhancing reforms in the tax-benefit system on the basis of optimal tax theory. Section 3 demonstrates the main features of our applied general equilibrium model. Section 4 presents model simulations of concrete reforms in the Netherlands to see which reforms improve efficiency. Finally, Section 5 concludes.

\section{Optimal tax theory as a guide for reform}

Optimal tax theory provides a good starting point for an analysis of the equityefficiency trade-off. The theory reveals that the optimal marginal tax schedule-i.e. 
the tax structure that achieves equity goals with minimal distortions in the labour market-is found to depend on at least five factors. ${ }^{1}$ First, there are two factors that determine the benefits from redistribution, namely:

(i) Pre-tax income inequality;

(ii) Social preference for redistribution.

If pre-tax inequality is large and society features much aversion against inequality, the government should put much effort in the redistribution of incomes from high to low-ability agents. In this paper, we make no attempt to measure the social benefits from equality.

The social benefits from equality should be weighed against the efficiency losses induced by redistribution. These efficiency costs are determined by the following three factors:

(iii) Elasticity of labour supply of various agents;

(iv) Elasticities at other decision margins;

(v) Population density at various decision margins.

The elasticity of labour supply (iii) determines the classical distortionary impact of marginal tax rates on the consumption/leisure choice. This distortion was already present in the original analysis of Mirrlees (1971). The larger is the elasticity, the bigger is the distortionary impact of redistributive taxation and the less redistribution is optimal. Redistributive policies may also distort other decision margins, such as the extensive margin of labour supply or the search and acceptance behaviour of the unemployed (iv). Finally, the optimal tax depends on the population density at various margins (v). If density is higher at some point in the income distribution, a marginal tax creates larger aggregate distortions so that the optimal tax rate is lower.

The optimal-tax literature reports a variety of results with respect to the optimal marginal tax schedule. In general, these findings can be understood by the variation in assumptions on the factors (i)-(v). The optimal tax schedule reported in applied optimal tax studies will thus depend on e.g. the calibration of the income distribution, the choice of decision margins, the corresponding elasticities at these margins, and the disaggregation with respect to agents and households. Overall, optimal tax theory reveals that distortions can best be avoided if elasticities are high and if the density in the income distribution is high. Below, we summarise some of the main policy lessons from applied optimal tax models.

\subsection{A linear tax structure}

Mirrlees (1971) simulates the optimal marginal tax schedule for a utilitarian social welfare function, Cobb-Douglas preferences in consumption and leisure, and a lognormal distribution of abilities. He concludes that " . . the most striking feature of the results is the closeness to linearity of the optimal tax schedules" (p. 206). This result

\footnotetext{
${ }^{1}$ The seminal contribution to this literature is Mirrlees (1971). A recent review of subsequent literature and its policy relevance can be found in Sørensen (2007).
} 
provides efficiency grounds for a flat income tax structure. This flat tax has considerable appeal to policy makers. Recently, a number of Eastern European countries have introduced flat income tax systems with a single rate on labour income (see Keen et al. 2006 for a review and discussion of these reforms). Also other European countries consider reforms in this direction.

Subsequent contributions in the optimal tax literature have raised doubts on the optimality of the linear income tax schedule. Tuomala (1990) finds that the optimal marginal tax schedule is sensitive to the underlying assumptions. In fact, the optimal structure is non-linear if social welfare functions feature relatively high inequality aversion and if labour supply responses are different between agents. The non-linear structure is more efficient because it employs more information on individual earnings so that it can achieve the same redistribution with less dead weight loss.

With respect to the shape of the non-linearities, early contributions to the literature conclude that the optimal marginal income tax features an inverse-U shape, i.e. high for middle incomes and low for low and high incomes. If abilities are bounded above, the optimal marginal tax on the highest ability agent even goes down to zero (Seade 1977, 1982). Intuitively, a positive marginal tax would not contribute to redistribution but does distort labour supply of this person. Tuomala (1990) shows, however, that these results are very local and of little practical relevance.

More recently, Diamond (1998) and Saez (2001) have used pre-tax income distributions for the United States and a uniform positive labour supply elasticity to show that the optimal marginal tax structure typically features a U-shaped pattern: high at the bottom and top of the distribution and low for middle incomes. This result is driven by population densities. Intuitively, a negative average tax for the poor is necessary to redistribute income. It should be phased out with income in a range where the population density is not so high. In the United States, this is just above the minimum income. Beyond this level, the optimal marginal tax falls as population density increases and marginal taxes create large aggregate distortions in labour supply. It may rise again for higher incomes if inequality aversion is sufficiently large. ${ }^{2}$

Still, high marginal tax rates at the bottom and top of the income distribution are often criticised in European policy debates. High marginal income tax rates at the top are often held responsible for severe distortions in labour supply (see e.g. Prescott 2004). Reducing these rates has therefore been advocated in many European countries. During the 1980s and 1990s, countries have indeed substantially reduced their top marginal tax rates. High marginal tax rates at the bottom of the labour marketknown as the poverty trap-are held responsible for severe labour market distortions in Europe. Indeed, unemployment in Europe is concentrated at the bottom of the labour market. In this connection, some have proposed to replace means-tested transfer schemes by a negative income tax or: basic income (see e.g. Atkinson 1995). It provides an effective floor in the income distribution and avoids complexities and administrative difficulties in gathering information about eligibility to means-tested social transfers. Moreover, non-compliance and moral hazard would disappear. The

\footnotetext{
${ }^{2}$ The U-shaped pattern obtained from empirical income distributions opposes the zero marginal tax rate at the top of the income distribution found by Seade $(1977,1982)$. The reason is that the empirical income distribution is thicker at the top than the assumed log-normal distributions in the earlier studies.
} 
abolishment of means-tested benefits would reduce marginal tax rates at the bottom of the income distribution and thus alleviate the poverty trap. Yet, it does not comply with the U-shaped form of the optimal marginal tax schedule emphasised by empirically simulated optimal tax models.

\subsection{Taxation of couples}

Empirical evidence reveals that female labour supply is more elastic than male labour supply. Optimal-tax principles then imply that labour income of females should be taxed at a lower marginal rate than labour income of males, see e.g. Rosen (1977). However, laws typically do not permit such discrimination on the basis of gender. Hence, the government should look for indicators that are correlated with it. As argued by Boskin and Sheshinski (1983), females are often secondary earners in families. They suggest that an optimal income tax should therefore differentiate marginal tax rates between primary and secondary earners. This requires selective taxation measures for secondary earners (Kleven et al. 2006).

The responsiveness of secondary earners also matters for the taxation of couples (Apps and Rees 2003; Kleven et al. 2006). Here, we can distinguish between joint taxation and individual taxation. Under individual taxation, each family member is taxed separately, independent of the income of other household members. Under joint taxation, the tax liability is determined by total family income. In progressive tax systems, the two principles score differently with respect to labour-market incentives for secondary earners. Indeed, compared to joint taxation, individual taxation imposes a lower marginal tax burden on the labour income of secondary earners. Individual taxation is therefore more efficient if secondary earners feature a relatively high elasticity. It is adopted in Denmark, Sweden, Finland, United Kingdom, Belgium and Austria and the Netherlands. Joint taxation is adopted in United States, Germany, France, Portugal and Spain.

\subsection{In-work tax credits}

Empirical studies on labour supply elasticities emphasise that the extensive margin of participation tends to be more elastic than the intensive margin of hours worked (Evers et al. 2005). Efficiency concerns thus call for smaller distortions at the participation margin (Boone and Bovenberg 2004). In light of this, Saez (2002) advocates in-work tax credits for low income workers. Such credits have gained popularity during recent decades in a number of countries. For instance, the United States has introduced the earned income tax credit and the United Kingdom the working family tax credit. These credits aim at alleviating poverty among the working poor, but also have important implications for labour-market incentives. On the one hand, the credits encourage labour-market participation of low-skilled people by raising the income gap between those inside and outside the labour market. On the other hand, they make the tax system more progressive by benefiting workers with low incomes compared to those with high incomes. Tax progression reduces labour-supply incentives at the intensive margin. 
Several empirical studies have analysed the labour-market implications of in-work tax credits. Eissa and Liebman (1996) and Meyer and Rosenbaum (2001) find positive effects of the American earned income tax credit on the participation margin. Blundell et al. (2000) find that the working families' tax credit has raised aggregate participation in the United Kingdom. Moreover, Keane and Moffitt (1996) and Meyer (2002) conclude that there is no significant adverse effect of earned income tax credits on the intensive margin of labour supply, i.e. hours worked. Hence, the aggregate impact of these credits on employment is likely to be positive. Note, however, that none of these studies considers a balanced budget reform where in-work tax credits are financed by general tax increases.

\section{MIMIC: an AGE model for the Netherlands}

This section presents an applied general equilibrium model-MIMIC — that is used to explore potentially promising reforms in the Dutch tax-benefit system. The model is comprehensive in modelling various decision margins, it contains a high degree of disaggregation in the household sector, and it is calibrated for a typical European country: the Netherlands. ${ }^{3}$

\subsection{Households}

MIMIC contains a disaggregated household model aimed at describing the impact of the tax-benefit system on labour supply and the income distribution. Table 1 gives a quick overview of this disaggregation. First, the model accounts for heterogeneity in various dimensions, including skill, cohabitation, the presence of children, whether household members participate or are eligible for social benefits, and age (see upper part of Table 1). Overall, the model distinguishes 40 different household types.

Within each type, we make a further distinction with respect to discrete options for labour supply (see middle part of Table 1). For instance, primary earners can choose their optimal working time between the options $80 \%, 100 \%$ and $120 \%$ of a full-time equivalent. Secondary earners and singles face more options. Secondary earners in couples can also opt for voluntary non-participation. The option that an individual chooses is derived from utility maximisation, with consumption and leisure as arguments, subject to a household budget constraint. The preference for leisure is heterogeneous across agents. We use a uniform distribution of this preference parameter to calibrate the high share of part-time work of secondary earners and single persons in the Netherlands. Hence, part-timers feature a relatively high marginal utility of leisure. In determining labour supply of couples, we assume that each partner makes an individual decision, given an average income from his or her spouse.

In interpreting the labour supply responses to changes in prices and incomes, the traditional income and substitution effects are at work. Hence, if the marginal tax rate declines, labour supply increases on account of the substitution effect. A lower

\footnotetext{
${ }^{3}$ See Bovenberg et al. (2000) for a core version of MIMIC. A description of the full model and its calibration can be found in Graafland et al. (2001).
} 
Table 1 Structure of the household model in MIMIC

1. Types: individual characteristics

Skill

Low skilled or high skilled agents

Cohabitation

Single or in couple

Children

With or without children

Labour-market status

Working or receiving a social benefit (unemployment, disability or welfare)

Age

Students $>18$; workers $<55$; workers $55-64$; or pensioners $>65$

2. Options: Choice of working time per individual

Primary earner in couple

Secondary earner in couple

Singles

3. Wage distribution

Each type and option
80-100-120\% of full-time equivalent

0-30-50-80-100\% of full-time equivalent

50-80-100-120\% of full-time equivalent

average tax exerts a positive income effect, which reduces labour supply. Based on a meta analysis of labour-supply elasticities by Evers et al. (2005), we set utility parameters such that the uncompensated labour-supply elasticity equals 0.5 for secondary earners, 0.1 for primary earners and 0.25 for singles.

Within each combination of household-hours type, we employ a wage distribution based on Dutch microdata (lower part of Table 1). We distinguish 10 income classes for each group and base the density of each class on the data for 1992. The average wage levels in the model are updated on the basis of realised wage growth in the Netherlands until 2006. For each income class, we derive disposable income by applying the Dutch tax-benefit system to the gross incomes. The after-tax disposable incomes and the marginal tax burdens determine labour supply behaviour.

\subsection{Firms}

Labour demand for high-skilled and low-skilled workers is derived from firms that maximise profits subject to a CES production technology. The first-order conditions reveal that labour demand depends on the relative wage costs for the respective types of labour. Based on time series estimates for the Netherlands, the substitution elasticity between high-skilled and low-skilled workers is set at 1.15 . The substitution elasticity between capital and labour is set at $0.25 .{ }^{4}$ Economic profits originate from monopolistic competition without free entry. Hence, firms set prices as a mark-up over marginal production costs. ${ }^{5}$ This setting allows for endogenous terms-of-trade effects. As the export elasticity is set at a high value of -5 for this small open economy, these effects are of minor importance for our simulations.

\footnotetext{
${ }^{4}$ This may seem small compared to the calibration of other applied general equilibrium models. It is, however, consistent with the majority of empirical findings, see e.g. Chirinko (2002).

${ }^{5} \mathrm{We}$ do not consider taxes on rents. The reason for introducing economic profits is that employers and unions negotiate over this rent, which explains involuntary unemployment. Rents could alternatively be modelled as the return from a fixed factor in production.
} 


\subsection{Union bargaining}

Wages are obtained from a right-to-manage model. In bargaining over wages, trade unions exploit their monopsony power to reap part of the rents earned in production. However, by setting wages above the market clearing level, trade unions create unemployment which they value negatively. Unions thus face a trade off between high wages and low unemployment. An important specification in the right-to-manage model is the fall-back position of the trade union. In our model, it depends on unemployment benefits and an untaxed informal wage. The latter is modelled as a function of labour productivity and the price of consumption. Labour productivity is a proxy for the wage rate in the black market, while the price of consumption reflects the value of household production. This specification yields a non-linear wage equation in which several institutional variables enter. The non-linear equation has been estimated using Dutch time-series data (see Graafland and Huizinga 1999). In linearised form and evaluated in the initial equilibrium of MIMIC, it reads as follows (where only parameters are presented that are relevant for our analysis):

$$
\log W=\log h+0.3 \log R R-0.6 \log \left(1-T_{\mathrm{a}}\right)+0.1 \log \left(1-T_{\mathrm{m}}\right)-0.1 \log U,
$$

where $W$ is the real producer wage and $h$ stands for labour productivity. The positive coefficient for the replacement rate $(R R)$ reflects larger bargaining power of the union if social benefits increase. Higher benefits thus raise wage demands. The average tax rate enters the wage equation via $\left(1-T_{\mathrm{a}}\right)$. This is because the untaxed informal wage is part of the outside option of the union. Higher average labour taxes therefore strengthen the relative bargaining position of the union and increase wage demands. The marginal tax rate enters the wage equation via $\left(1-T_{\mathrm{m}}\right)$. This term exerts a positive effect on wages. With a low marginal tax rate, the trade union will find it more attractive to bid for higher wages since a larger part of additional wage increases are absorbed by government in the form of taxes. The elasticity of 0.1 for the unemployment rate $(U)$ is consistent with a consensus estimate from empirical studies reported by Blanchflower and Oswald (2005).

Wages for low skilled and high skilled workers are determined as a weighted average of a macro wage equation and a skill-specific wage equation (with weights of $1 / 2$ ). This is based on empirical findings of sectoral wages in the Netherlands by Graafland and Lever (1996). In the macro wage equation, the institutional variables, $T_{\mathrm{a}}, T_{\mathrm{m}}$ and $R R$ are computed as averages for all workers. In the skill-specific wage equation, the variables reflect averages for respective skill groups.

MIMIC uses a non-linear version of the wage equation (1), see Graafland and Huizinga (1999). One non-linear effect deserves special attention, as it plays an important role in our simulations. This is the positive interaction between the replacement rate and the unemployment rate. Intuitively, a high unemployment rate makes it more important for trade unions to care about the outside option since more union members face the fall-back income. Accordingly, the elasticity of the replacement rate rises in the rate of unemployment. As the unemployment rate is higher for lowskilled workers than for high-skilled workers, the replacement rate of the low-skilled causes relatively large increases in the wages of the low skilled. 


\subsection{Search-matching}

In addition to structural unemployment caused by unions, MIMIC also captures frictional unemployment due to imperfect matching on the labour market. Frictional unemployment is specified separately for low-skilled and high-skilled workers.

The model assumes an exogenous rate of job quits that leads to vacancies. At the same time, there is an exogenous rate of job lay-offs that causes unemployment. We model the steady state of a matching process between these vacancies and the unemployed searching for work. The more efficient job matching becomes, the lower are the search costs for employers to fill vacancies and the higher is number of vacancies posted. Thus, more efficient matching reduces the frictional rate of unemployment.

Matching efficiency depends on the net benefit replacement rate in two ways. First, the unemployed endogenously determine their search effort by trading off leisure against job search. A high replacement rate reduces the incentives for job search and thus reduces the efficiency of job matching. Second, a higher replacement rate raises the reservation wage of the unemployed in deciding about accepting a job offer or continue searching. The unemployed are thus less willing to accept an offer if the replacement rate is higher.

\section{Analysing reforms in the Dutch tax-benefit system}

We perform various simulations with MIMIC. They can be interpreted as an analysis of comparative statics. All simulations represent balanced-budget reforms. Personal income tax rates are always adjusted (each with the same percentage points) to maintain the public budget balanced ex-post, i.e. after behavioural responses have been taken into account.

In presenting simulation outcomes, we concentrate on two types of variables reflecting equity and efficiency. The equity effects are presented by means of net disposable income ratios for different groups. For instance, the ratio of average incomes of high-skilled/low-skilled workers represents equality in the income distribution among workers. We also present the replacement ratio, which involves a weighted average of the net benefit/net wage ratio for various workers and where weights are based on populations in employment. Regarding efficiency, we present the effects on hours worked for various groups, the participation rate of secondary earners (labelled 'female participation rate'), the unemployment rate, and aggregate employment.

Section 4.1 analyses two flat tax proposals and a basic income. The flat tax reforms replace the current progressive tax structure with increasing marginal tax rates. In 2006 , tax rates on labour income range from $34 \%$ for incomes up to $€ 17,000,41 \%$ for incomes between $€ 17,000$ and $€ 30,000,42 \%$ for incomes between $€ 30,000$ and $€ 53,000$ and $52 \%$ for incomes above $€ 53,000$. The system contains a general tax credit of $€ 2,000$. The basic income replaces means-tested benefits and subsidies that are provided to the poor.

Section 4.2 analyses two reforms in the taxation of couples. First, while the Dutch tax system is largely individualised, partners in single-earner couples can still transfer their general tax credit of 2,000 euro to the primary earner. We consider the individualisation of this credit. Second, the Dutch system contains a tax credit for secondary 
earners in couples, which is conditional on having children under 12, both partners working, and a partner income of at least $€ 4,500$. In that case, the partner with the lowest income in the family receives a credit of $€ 600$ per year. We consider an extension of this selective tax relief for secondary earners.

Section 4.3 explores selective in-work tax credits for low incomes. Today, the Dutch system contains an earned income tax credit with a maximum of $€ 1,350$. It features a linear phase-in range between $€ 8,000$ and $€ 16,000$ and no phase-out range. We explore various extensions of this credit.

\subsection{Flat tax reforms}

We explore three flat income tax reforms. The first two aim to cut the top marginal tax rate. In the first version, we replace the current rate structure by a flat tax rate of $37.5 \%$. This rate keeps the government budget balanced. The general tax credit remains unchanged. In the second flat-tax reform, we increase the general tax credit by $€ 1,400$. At the same time, we raise the flat tax rate to $43.5 \%$ to keep the government budget balanced. The extra tax credit applies only to people with a positive income and cannot be transferred by a non-participating partner to its spouse. ${ }^{6}$ The third simulation is the introduction of a basic income of $€ 550$ euro per month for all individuals above the age of 18 . The basic income replaces existing income transfers, such as welfare benefits, basic pensions, student grants, the general tax credit and the labour tax credit. ${ }^{7}$ To finance the basic income, we replace the current progressive tax system by a flat tax of $53.5 \%$ on all income to keep the government budget balanced. Hence, the top marginal tax rate increases, rather than falls. The effects of the three reforms are presented in Table 2.

The $37.5 \%$ flat tax raises the income differential between high-skilled and lowskilled workers. This is reflected in $1.5 \%$ increase in the ratio of income between high and low skilled workers. The $43.5 \%$ flat tax yields smaller effects on the income distribution as people earning low incomes are compensated by the higher tax credit. This benefits lower incomes more than higher incomes. The middle income groups typically lose. Hence, the $43.5 \%$ flat tax redistributes the tax burden from low and high incomes towards the middle income groups. Overall, the ratio of high and low skilled labour incomes remains unchanged. The basic income benefits low-skilled workers more than high-skilled workers and reduces the income ratio by $7.6 \%$.

The $37.5 \%$ flat tax reduces the marginal tax rates for many workers. On average, the decline is $2.9 \%$. This increases labour supply incentives due to substitution from leisure to consumption. Overall, labour supply expands by $1 \%$. The increase in hours worked does not apply to all individuals. Most primary earners and single persons face lower marginal tax rates as they are taxed at the margin in the higher tax brackets. Hence, these groups work longer hours. Many secondary earners in couples hold parttime jobs where they are taxed at the margin in the first bracket. The increase in the

\footnotetext{
${ }^{6}$ In both reforms, we maintain a lower rate in the first two brackets for the elderly above 65 as they do not pay premiums for the pay-as-you-go pension system. Hence, the tax structure for the elderly is not flat.

${ }^{7}$ Single persons and single parents maintain to receive supplementary welfare benefits. We reduce the level of unemployment benefits and disability benefits with the basic income. Hence, there remains only a top-up insurance for unemployment and disability.
} 
Table 2 Effects (in \% changes unless indicated) of two budgetary neutral flat tax proposals

\begin{tabular}{lccc}
\hline & Flat tax 37.5\% & $\begin{array}{l}\text { Flat tax } 43.5 \% \text { \& higher } \\
\text { general tax credit }\end{array}$ & $\begin{array}{l}\text { Flat tax 53.5\% } \\
\text { \& basic income }\end{array}$ \\
\hline Effects on distribution & & & \\
Ratio high skilled/low skilled & 1.5 & 0.0 & -7.6 \\
Mean of marginal tax rates (abs. dif) & -2.9 & 0.3 & 7.8 \\
Mean of replacement rates (abs. dif) & -1.7 & 0.1 & -2.6 \\
Effects on labour market & & & \\
Labour supply in hours & 1.0 & -0.3 & -5.3 \\
$\quad$ primary earners & 1.2 & 0.1 & -1.4 \\
$\quad$ secondary earners & 0.0 & -0.2 & -8.8 \\
$\quad$ single persons & 1.0 & -1.2 & -1.4 \\
Female participation rate & -1.7 & 1.5 & -3.8 \\
Employment & 1.4 & -0.3 & -1.9 \\
Unemployment rate (abs. dif) & -0.1 & -0.1 & \\
\hline
\end{tabular}

Source: MIMIC simulations

tax rate from 34 to $37.5 \%$ discourages them to work longer hours or to occupy small part-time jobs. Accordingly, the female participation rate drops by $1.7 \%$. Working females who work longer hours increase their hours worked due to lower marginal tax rates in the higher tax brackets. On balance, the effect on partner labour supply in hours is negligible. Overall, the simulations suggest that the $37.5 \%$ flat tax causes more inequality in the income distribution, but it reduces distortions in labour supply. It thus illustrates the classical trade-off between equity and efficiency.

Under the $43.5 \%$ flat tax, labour supply distortions become larger, rather than smaller: labour supply falls by $0.3 \%$. The reason is that the marginal tax burden is shifted from people at the bottom and top of the income distribution towards the middle incomes. The lower tax at the bottom encourages non-working partners to participate in small part-time jobs. Female participation thus expands by $1.5 \%$. Also high-skilled primary earners, who face a lower marginal tax rate, raise their hours worked. The higher marginal tax on middle incomes exerts negative effects on labour supply. This effect is relatively sizable for two reasons. First, it raises the marginal tax for the more densely populated group, which renders the distortions larger. Second, it raises the marginal tax primarily for secondary earners and singles who feature larger elasticities than male breadwinners. Labour supply of partners and singles fall by, respectively, 0.2 and $1.2 \%$, while male breadwinner labour supply rises by only $0.1 \%$. Hence, a flat tax yields less efficient redistribution than the current progressive rate structure in the Netherlands.

The third column of Table 2 shows the effects of the basic income proposal. This reform reduces the replacement rate for low incomes. On average over the population, the replacement rate falls by $2.6 \%$ points. The lower replacement rate induces wage moderation, encourages job search and job acceptance and thus reduces the unemployment rate by $1.9 \%$. The downside of the basic income is a higher marginal tax 
burden. Indeed, a 53.5\% tax is necessary to finance the basic income, which increases the marginal tax burden on average by $7.8 \%$. This reinforces the wage moderating impact of the reform and contributes to the reduction in equilibrium unemployment. However, the higher marginal tax burden reduces the incentives for labour supply across the board. Overall, labour supply falls by $5.3 \%$ and the female participation rate drops by $10 \%$. On balance, aggregate employment falls by $3.8 \%$. The negative income tax thus tends to fail in improving the equity-efficiency trade-off. Removing the poverty trap while maintaining the minimum income guarantee will exacerbate the overall distortionary impact of the tax system on labour supply as it hurts labour supply incentives of the densely populated group of middle incomes. This is why the optimal marginal tax schedule features high marginal taxes for low income groups. The poverty trap thus tends to be part of an optimal tax schedule and minimises the distortionary cost associated with redistribution to the poor.

\subsection{Taxation of couples}

Selective marginal tax relief for secondary earners in couples is explored in two forms: an extension of the selective earned income tax credit for secondary earners with children and an individualisation of the general tax credit. The proposed selective tax credit is linearly phased in between 0 and $€ 12,000$ and that has a maximum of $€ 2,700$. It features no phase-out range. The government budget is balanced by an increase in all personal income tax rates by approximately $1 \%$ point. Individualisation is analysed by abolishing the right to transfer the general tax credit to the working spouse. ${ }^{8}$ This saves 1.75 billion euro. It is used to cut income tax rates by $0.75 \%$ point. The effects of both reforms are presented in Table 3 .

The selective credit for secondary earners raises the marginal tax burden for most workers due to a higher personal income tax rate. This reduces hours worked by primary earners and singles. The credit reduces the tax burden at the extensive margin of secondary earners. Accordingly, the female participation rate rises by $4.7 \%$. This primarily consists of part-time jobs. Female labour supply in hours expands by $2.2 \%$. On balance, the higher female participation rate dominates the decline in hours by males and singles so that aggregate labour supply expands by $0.1 \%$. The unemployment rate falls because the credit is conditional on both partners working. Hence, the credit encourages unemployed males and females to search for work and accept jobs. This improves the efficiency of job matching and reduces unemployment. Overall, aggregate employment rises by $0.4 \%$. We conclude that selective tax relief for the elastic group of secondary earners has the potential to raise labour-market participation, both in terms of persons and in terms of total labour hours. It comes at the expense of a lower disposable income for single-earner couples. The income ratio between high-skilled and low-skilled workers does not change, on average.

Individualisation of the general tax credit raises the tax burden on single-earner couples, while it reduces it on other households. Accordingly, the ratio of net income for single-earner couples and two-earner couples falls by $5.5 \%$. Singles and

\footnotetext{
${ }^{8}$ This reform will reduce the net social minimum income in the Netherlands for couples. A number of social benefits are indexed by this level of social minimum. To prevent this, we raise the gross social minimum to compensate for this effect of the reform.
} 
Table 3 Effects (in \% changes unless indicated) of reforms in the taxation of couples

Secondary earner tax credit Individualised general tax credit

\begin{tabular}{lrr} 
Effects on distribution & \\
Ratio high skilled/low skilled & -0.0 & 1.8 \\
Ratio single earner/two earner & -2.7 & -5.5 \\
Mean of marginal tax burdens (abs. dif) & 0.5 & -0.6 \\
Mean of replacement rates (abs. dif) & 0.0 & -0.1 \\
& & \\
Labour market effects & 0.1 & 1.0 \\
Labour supply in hours & -0.3 & 0.1 \\
$\quad$ primary earners & 2.2 & 4.8 \\
secondary earners & -0.3 & 0.4 \\
$\quad$ single persons & 4.7 & 9.5 \\
Female participation rate & 0.4 & 1.2 \\
Aggregate employment & -0.2 & 0.1 \\
Unemployment rate (abs. dif) & & \\
\hline
\end{tabular}

Source: MIMIC simulations

primary earners substitute consumption for leisure and raise labour supply due to a lower marginal tax burden. Secondary earners respond more. Table 3 shows that the female participation rate increases by $9.5 \%$ while hours worked expands by $4.8 \%$. The reason is that the substantial increase in the after-tax income difference between one-earner and two-earner couples makes it attractive for partners to enter the labour market. These partners primarily occupy part-time jobs. As the replacement rate remains virtually unchanged and marginal tax rates fall, there is a small upward effect on wages, which exacerbates the imperfections in the right-to-manage model. This raises equilibrium unemployment. Overall, we find an expansion of total employment by $1.2 \%$. Individualising the Dutch tax system will thus raise employment. It comes at the expense of single-earner families, especially those with low skills. In that respect, the reform does not fully escape the equity-efficiency trade-off.

\subsection{In-work tax credits}

We simulate seven alternative in-work tax credits in the Netherlands. They differ with respect to the phase-in range, the flat range and the phase-out range. Each credit costs 2.5 billion euro ex ante. The government budget is closed by means of an increase in the income tax rates by approximately $1 \%$ point. The reforms thus make the tax system more progressive. The different designs of the credit are illustrated in the top rows of Table 4 . The first credit is a fixed amount of $€ 360$ for each worker. The other credits feature a phase-in range between an annual earned income of $€ 8,000$ and $€ 16,000$. The second credit of $€ 390$ features no phase-out range. Other credits differ with respect to their flat and phase-out ranges. The third and fourth credits are very much targeted on low incomes: they feature no flat range and are rapidly phased out with annual incomes between $€ 16,000$ and $€ 20,000$ or $€ 24,000$. The 
Table 4 Effects (in \% changes unless indicated) of in-work tax credits, financed by higher income tax rates

\begin{tabular}{|c|c|c|c|c|c|c|c|}
\hline \multicolumn{8}{|l|}{ Design of the credit } \\
\hline Credit & $€ 360$ & $€ 390$ & $€ 2,600$ & $€ 1,800$ & $€ 1,600$ & $€ 800$ & $€ 560$ \\
\hline Phase-in range (in $€ 1,000$ ) & - & $8-16$ & $8-16$ & $8-16$ & $8-16$ & $8-16$ & $8-16$ \\
\hline Flat range (in $€ 1,000$ ) & $0-\infty$ & $16-\infty$ & - & - & $16-20$ & $16-24$ & $16-32$ \\
\hline Phase-out rang (in $€ 1,000$ ) & - & - & $16-20$ & $16-24$ & $20-24$ & $24-32$ & $32-40$ \\
\hline \multicolumn{8}{|l|}{ Effects on distribution } \\
\hline Ratio high skilled/low skilled & -0.7 & -0.5 & -2.1 & -2.2 & -2.5 & -1.6 & -1.0 \\
\hline Mean of marginal tax burdens (abs. dif) & 0.6 & 0.4 & 2.9 & 1.7 & 2.3 & 1.8 & 1.1 \\
\hline Mean of replacement rate (abs. dif) & -0.8 & -0.8 & -0.1 & -0.2 & -0.1 & -0.5 & -0.7 \\
\hline \multicolumn{8}{|l|}{ Labour market effects } \\
\hline Labour supply in hours & -0.2 & 0.1 & -1.2 & -0.9 & -0.7 & -0.4 & -0.2 \\
\hline primary earners & -0.2 & -0.2 & -0.8 & -0.7 & -0.6 & -0.5 & -0.5 \\
\hline secondary earners & 0.5 & 0.4 & 0.4 & 0.1 & -0.2 & 0.1 & 0.6 \\
\hline single persons & -0.5 & 0.2 & -2.6 & -1.7 & -1.0 & -0.4 & -0.1 \\
\hline Female participation rate & 1.5 & 0.3 & 3.6 & 2.4 & 1.4 & 1.1 & 0.6 \\
\hline Aggregate employment & 0.1 & 0.5 & -1.0 & -0.6 & -0.3 & 0.0 & 0.3 \\
\hline Unemployment rate (abs. dif) & -0.27 & -0.27 & -0.37 & -0.34 & -0.32 & -0.35 & -0.31 \\
\hline low skilled (abs. dif) & -0.6 & -0.6 & -0.9 & -0.7 & -0.6 & -0.7 & -0.6 \\
\hline high skilled (abs. dif) & -0.2 & -0.2 & -0.2 & -0.2 & -0.3 & -0.3 & -0.3 \\
\hline
\end{tabular}

Source: MIMIC simulations

last three credits feature a flat range and a phase-out range for successively higher annual incomes.

Table 4 reveals that all in-work tax credits reduce inequality. This is reflected in a smaller ratio of high-skilled and low-skilled labour income. The reason is that the value of a credit is fixed for all eligible workers. The higher tax rate, in contrast, hurts higher incomes more than lower incomes. Therefore, even the fixed in-work tax credit shifts the tax burden from low to high incomes. Targeted credits that only apply to people collecting lower incomes reduce inequality much more.

In-work tax credits reduce the replacement rate because only workers are eligible, not social benefit recipients. The latter group actually faces a decline in income due to higher income tax rates. Hence, the incomes between people inside and outside the labour market becomes more dispersed.

The marginal tax burden rises for two reasons. Fist, higher tax rates are necessary to finance the in-work tax credit. Second, marginal tax rates rise in the phase-out range of the credit. Yet, the marginal tax in the phase-in range declines. On balance, the marginal tax burden rises for the majority of workers, especially under the targeted credits.

The simulations reveal that the unemployment rate falls by between 0.27 and $0.37 \%$, depending on the precise design of the credit. The lower replacement rate encourages the unemployed to search for work and to accept jobs, thereby improving matching efficiency and reducing frictional unemployment. Moreover, the lower 
replacement rate, together with the higher marginal tax burden, moderates wage demands by trade unions. This further reduces unemployment. The decline in unemployment is concentrated among the low skilled, especially under the more targeted credits. This is caused by the positive interaction between the replacement rate and the unemployment rate in the wage equation (1). It implies that the reduction in the replacement rate for low-skilled workers causes a relatively strong reduction in wages and, therefore, in the unemployment rate.

In-work tax credits stimulate the participation of secondary earners. Indeed, nonparticipating partners find it more attractive to participate in part-time jobs. This is reflected in the positive effect on the female participation rate in Table 4: it rises by between 0.3 and $3.6 \%$. Credits that reduce the marginal burden in the phase-in range may further encourage female labour supply by reducing the marginal tax burden on small part-time jobs.

Others, like primary earners and singles, reduce their hours worked as higher marginal taxes induce substitution into leisure. Labour supply of primary earners falls between 0.2 and $0.8 \%$. Labour supply of singles falls in most simulations, especially when the most targeted credits are introduced with rapid phase-out ranges. The reason is that the population of singles in the Netherlands is dense in the range between $€ 16,000$ and $€ 20,000$. Hence, distortions imposed by marginal tax rates in this range are large. A more gradual phasing out of the credit at higher incomes mitigates the adverse labour supply effects on singles.

The labour supply effect for secondary earners is the balance of positive participation effects (and hours effects for partners in the phase-in range) and negative hours effects for partners in the phase-out range. On balance, secondary workers increase labour supply with most credits. If the credit is phased out between $€ 16,000$ and $€ 32,000$, however, the negative effect on hours worked dominates. Overall, Table 4 shows that aggregate labour supply drops in most reforms, but not all. For the credit of $€ 390$ with a phase-in range but no phase-out, aggregate labour supply expands by $0.1 \%$. Other credits reduce labour supply by between $0.2 \%$ when least targeted to $1.2 \%$ when most targeted.

Our simulations thus reveal that in-work tax credits for low labour incomes are effective to raise participation at the extensive margin of labour supply. Thereby, more targeting reinforces the positive impact at the participation margin, i.e. in reducing unemployment and raising the female participation rate. However, targeted in-work credits also cause larger disincentives to work longer hours as they increase marginal tax rates elsewhere. Hence, we face a trade-off between stimulating participation at the extensive margin and encouraging hours worked at the intensive margin of labour supply. It appears that phasing out just above the minimum wage is counterproductive in the Netherlands since it induces large adverse labour supply effects on singles who often occupy part-time jobs. Phasing out higher in the income distribution is less distortionary. On balance, selective in-work tax credits can then raise aggregate employment. Depending on their design, in-work tax credits thus have the potential to improve the equity-efficiency trade off. 


\section{Conclusions}

This paper explores reforms in the tax-benefit system that have the potential to improve equity-efficiency trade-off. Optimal tax theory provides guidance to this. In particular, efficient redistribution calls for low marginal tax rates at decision margins that are relatively elastic and where population densities are high. We explore reforms in the Dutch tax-benefit system that meet these conditions by using an applied general equilibrium model for the Netherlands. In the model, various decision margins and population densities are calibrated.

We find that flat tax reforms do not raise employment if aggregate income inequality is maintained. If a flat tax is combined with a basic income, it can remove the poverty trap and reduces low-skilled unemployment. Yet, it hurts overall labourmarket performance. Hence, the poverty trap seems an inevitable consequence of redistribution and reflects the lowest efficiency cost induced by equality.

Shifting the tax burden away from elastic secondary earners may help to raise aggregate employment levels. In case of the Netherlands-which features a high share of part-time work - this may be achieved by a progressive tax rate structure, a completion of the individualisation of the income tax, or an extension of selective in-work tax credits for secondary earners.

Reforms that reduce the tax burden at the extensive margin of labour supply have the potential to raise employment. In-work tax credits for low incomes may reduce involuntary unemployment and boost female labour-market participation rates. The risk of these credits is, however, that they create larger distortions at the intensive margin of labour supply. These can more than offset the positive participation effects if the marginal tax rate increases for the densely populated groups. We find that phasing out in-work tax credits just above the minimum wage tends to create these severe labour-supply distortions.

Acknowledgement I thank an anonymous referee and Bas Jacobs for instructive comments.

\section{References}

Apps, P., \& Rees, R. (2003). The taxation of couples. Mimeo, University of Munich.

Atkinson, A. B. (1995). Public economics in action: the basic income/flat tax proposal. Oxford: Clarendon.

Blanchflower, D. G., \& Oswald, A. J. (2005). The wage curve reloaded (IZA Discussion Paper No. 1665).

Blundell, R., Duncan, A., McCrae, J., \& Meghir, C. (2000). The labour market impact of the working families' tax credit. Fiscal Studies, 21, 75-104.

Boone, J., \& Bovenberg, A. L. (2004). The optimal taxation of unskilled labor with job search and social assistance. Journal of Public Economics, 88, 2227-2258.

Boskin, M., \& Sheshinski, E. (1983). Optimal tax treatment of the family: married couples. Journal of Public Economics, 20, 281-297.

Bovenberg, A. L., Graafland, J. J., \& de Mooij, R. A. (2000). Tax reform and the Dutch labor market: an applied general equilibrium approach. Journal of Public Economics, 78, 193-214.

Chirinko, R. S. (2002). Corporate taxation, capital formation, and the substitution elasticity between labor and capital (CESifo Working Paper no. 707).

Diamond, P. A. (1998). Optimal income taxation: an example with a U-shaped pattern of optimal marginal tax rates. American Economic Review, 88, 83-95.

Eissa, N., \& Liebman, J. B. (1996). Labor supply response to the earned income tax credit. Quarterly Journal of Economics, 111(2), 605-637. 
Evers, M., de Mooij, R. A., \& van Vuuren, D. J. (2005). What explains the variation in estimates of labour supply elasticities? (CPB Discussion Paper 51), The Hague.

Graafland, J. J., \& Huizinga, F. H. (1999). Taxes and benefits in a non-linear wage equation. De Economist, $147,39-54$.

Graafland, J. J., \& Lever, M. H. C. (1996). Internal and external forces in sectoral wage formation: evidence from the Netherlands. Oxford Bulletin of Economics and Statistics, 58, 241-252.

Graafland, J. J., de Mooij, R. A., Nibbelink, A. G. H., \& Nieuwenhuis, A. (2001). Contributions to economic analysis: Vol. 251. MIMICing tax policies and the labour market. Amsterdam: North-Holland.

Keane, M., \& Moffitt, R. (1996). A structural model of multiple welfare program participation and labour supply. International Economic Review, 39, 553-589.

Keen, M., Kim, Y., \& Varsano, R. (2006). The 'flat tax(es)': principles and evidence (IMF Working Paper 06/218).

Kleven, H. J., Kreiner, C. T., \& Saez, E. (2006). The optimal taxation of couples (NBER Working Paper no. 12685).

Meyer, B. D. (2002). Labor supply at the extensive and intensive margins: recent tax and welfare policy and its effects. American Economic Review, 92, 373-379.

Meyer, B. D., \& Rosenbaum, D. T. (2001). Welfare, the earned income tax credit, and the labor supply of single mothers. The Quarterly Journal of Economics, 116, 1063-1114.

Mirrlees, J. A. (1971). An exploration in the theory of optimum income taxation. Review of Economic Studies, 38, 175-208.

Prescott, E. C. (2004). Why do Americans work so much more than Europeans (NBER Working Paper no. 10316).

Rosen, H. (1977). Is it time to abandon joint filing? National Tax Journal, 30, 423-428.

Saez, E. (2001). Using elasticities to derive optimal income tax rates. Review of Economic Studies, 68, 205-230.

Saez, E. (2002). Optimal income transfer programs: intensive versus extensive labor supply responses. Quarterly Journal of Economics, 117, 1039-1073.

Seade, J. K. (1977). On the shape of the optimal tax schedules. Journal of Public Economics, 7, $203-235$.

Seade, J. K. (1982). On the sign of the optimum marginal income tax. Review of Economic Studies, 49, 637-643.

Sørensen, P. B. (2007). The theory of optimal taxation: what is the policy relevance? International Tax and Public Finance, 14, 383-406.

Tuomala, M. (1990). Optimal income tax and redistribution. Oxford: Clarendon. 